\title{
Meat production characteristics of Turkish native breeds: I. Fattening, slaughter and carcass traits of lambs
}

\author{
Y. Aksoy ${ }^{1}$, M. Uğurlu², A. Önenç ${ }^{3}$, E. Şirin ${ }^{4}$, U. Şen ${ }^{5 \#}$, Ü. Çiçek ${ }^{6}$, Z. Ulutaş ${ }^{7}$ \& M. Kuran ${ }^{5}$ \\ ${ }^{1}$ Osmangazi University, Faculty of Agriculture, Department of Animal Science, 26160, Eskisehir, Turkey \\ ${ }^{2}$ Ondokuz Mayis University, Faculty of Veterinary Medicine, Department of Animal Science, 55139, Samsun, Turkey \\ ${ }^{3}$ Namik Kemal University, Faculty of Agriculture, Department of Animal Science, 59000, Tekirdag, Turkey \\ ${ }^{4}$ Ahi Evran University, Faculty of Agriculture, Department of Agricultural Biotechnology, 40100 Kirsehir, Turkey \\ ${ }^{5}$ Ondokuz Mayis University, Faculty of Agriculture, Department of Agricultural Biotechnology, 55139, Samsun, Turkey \\ ${ }^{6}$ Gaziosmanpasa University, Faculty of Engineering and Natural Sciences, Department of Food Engineering, 60250, \\ Tokat, Turkey \\ ${ }^{7}$ Omer Halisdemir University, Ayhan Sahenk Faculty of Agricultural Sciences and Technologies, Department of Animal \\ Production and Technologies, 51240 Nigde, Turkey
}

(Received 6 April 2018; Accepted 20 June 2018; First published online 2 August 2018)
Copyright resides with the authors in terms of the Creative Commons Attribution 4.0 South African Licence. See: http://creativecommons.org/licenses/by/4.0/za
Condition of use: The user may copy, distribute, transmit and adapt the work, but must recognise the authors and the South African Journal of Animal Science.

\begin{abstract}
The present study was conducted to determine the slaughter and carcass traits of male lambs of the Akkaraman (A), Morkaraman (M), Awassi (IW), Karayaka (KR), Kıvırcık (KV) and Middle Anatolian Merino (MAM) sheep breeds. Fattening of all lambs started when they were at 90 days at weaning and finished when they reached bodyweight of $40 \mathrm{~kg}$. The cold dressing percentage of lambs of $A, M$, and IW breeds were significantly lower than those of $\mathrm{KV}, \mathrm{KR}$ and MAM. Fat depth and muscle area were significantly greater in KV and MAM lambs than those of the other breeds. There were significant differences among breeds in shoulder, leg and lean weights. Weights of back loin in KV and MAM lambs were significantly greater than those of the other breeds. The highest values for carcass fleshiness were obtained in MAM and IW lambs, but they had a significantly lower carcass fatness score. There were significant differences among the breeds in carcass compactness and leg conformation. The results of the present study indicated that $A$ and MAM breeds could be recommended for desirable carcass characteristics.
\end{abstract}

Keywords: Carcass cuts, indigenous sheep breed, intensive lamb finishing, meat formation, SEUROP classification

\#Corresponding author: ugur.sen@omu.edu.tr

\section{Introduction}

Sheep breeding in Turkey is usually performed under extensive conditions, depending on pasture area, and is a primary source of income for traditional small farms in the rural population (Yilmaz et al., 2012). Nevertheless, traditional sheep breeding activities have diminished owing to increasing mechanization in agriculture and dwindling pasture areas, in addition to other reasons. On the other hand, the increasing human population and social and economic improvements in society have boosted the demand for red meat and meat products.

The consumption of red meat increases daily in developing countries such as Turkey, and producers are focused on satisfying consumer demand (Tufarelli et al., 2011). Lamb meat production systems are different in Turkey from European Union (EU) countries. Generally, lambs are slaughtered at low bodyweight in the western regions, and as yearling lambs in the eastern regions. In Turkey, the carcass yield per animal has not been increased to meet the meat demand of the growing human population. Hence, production levels per capita have regressed recently (Sen et al., 2011). Therefore, the meat production potential of indigenous sheep breeds should be determined, and lamb meat production and quality must be improved with new breeding strategies.

Sheep and lamb meat make important contributions to red meat production, amounting to $20 \%$ of the total meat production of Turkey (TurkStat, 2018). The vast majority of the sheep population of Turkey are 
native breeds, which are raised in various geographical regions, and total about 30 million (TurkStat, 2018). However, the present meat production performances of native sheep breeds are far from optimal (Ekiz et al., 2009). Akkaraman (A), Morkaraman (M) and Awassi (IW) are fat-tail breeds, and Karayaka (KR), Kıvırcık $(\mathrm{KV})$, and Middle Anatolian Merino (MAM) are thin-tail breeds, and are constitute approximately $80 \%$ of the sheep population (TurkStat, 2018). The A, M, IW, KV, KR and MAM breeds are well known for their fattening performances and carcass characteristics (Macit 2002; Ekiz et al., 2009; Yilmaz et al., 2009; Sen et al., 2011). However, there is a dearth of data from comparative studies about the slaughter and carcass characteristics of these breeds that have been performed under intensive conditions. The present study was therefore conducted to determine comparatively the slaughter and carcass characteristics of $A, M, I W, K R$, $\mathrm{KV}$, and MAM male lambs under an intensive feeding system. The results might assist in deciding which indigenous breed to use in sheep farming systems in Turkey.

\section{Materials and Methods}

The experiment was conducted at the Agricultural Research and Application Farm of Gaziosmanpasa University, Tokat, Turkey ( $40^{\circ} 31^{\prime} \mathrm{N}, 36^{\circ} 53^{\prime} \mathrm{E}$, and $650 \mathrm{~m}$ above the sea level). A total of 36 singleton male lambs of $A(n=6), M(n=6), \operatorname{IW}(n=6), \operatorname{KR}(n=6), K V(n=6)$ and MAM $(n=6)$ sheep breeds was used as experimental animals. They were randomly selected from the same flock of each breed after 90 days at weaning. After weaning all lambs were subjected to a fattening period and were slaughtered when they reached $40 \mathrm{~kg}$ live weight. Before the fattening period, all lambs were allowed to adapt for one week to the nutritional treatments. During the fattening period the lambs were fed concentrates containing $15 \%$ crude protein (Ankara Yem A.S., Ankara, Turkey) ad libitum and approximately $100 \mathrm{~g} /$ day alfalfa hay. All lambs were allowed water and a mineral supplement ad libitum. The nutrient contents of the feeds that were used during the fattening period are shown in Table 1.

Table 1 Chemical composition of concentrate feed and alfalfa hay

\begin{tabular}{lcc}
\hline Nutrient content & Concentrate & Alfalfa hay \\
\hline Dry matter (\%) & 93.10 & 94.00 \\
Crude protein (\%) & 15.20 & 15.00 \\
Crude oil (\%) & 2.23 & 0.74 \\
Crude ash & 8.60 & 10.30 \\
Acid detergent fibre & 29.41 & 59.75 \\
Neutral detergent fibre & 30.22 & 58.22 \\
Metabolic energy $(\mathrm{kJ} / \mathrm{kg})$ & 11262.49 & 7862.81 \\
\hline
\end{tabular}

All lambs were fasted overnight (approximately 16 hours) before slaughter. Lambs were weighed to determine slaughter weight and were slaughtered using standard commercial procedures. After slaughter, the weights of the hot carcass, pelt, head and visceral organs (heart, liver, lungs with trachea and spleen) were recorded. Carcasses were stored and cooled for 24 hours at $4{ }^{\circ} \mathrm{C}$, and then the weight of the chilled carcass was recorded. The cold carcasses were halved symmetrically and certain carcass measurements were taken with a volumetric stick and tape (Fisher \& De Boer, 1994; Russo et al., 2003; Vacca et al., 2008).

After carcass measurements, the other halves of the carcasses were divided into six main pieces, which consisted of the neck, foreleg, flank, shoulder, leg and back loin (Colomer-Rocher et al., 1988) (Figure 1). After carcass separation, the fat thickness of the longissimus dorsi muscle (LD) was measured between the 12th and 13th ribs with a digital compass. In addition, the surface of the $L D$ muscle was traced onto acetate paper to determine the cross-section area (Tufarelli et al., 2012). This area was then measured with a digital planimeter. The weights of the carcass pieces were determined with a balance with sensitivity of 1 gram. Each section was dissected physically to determine the meat, fat, and bone ratios. 


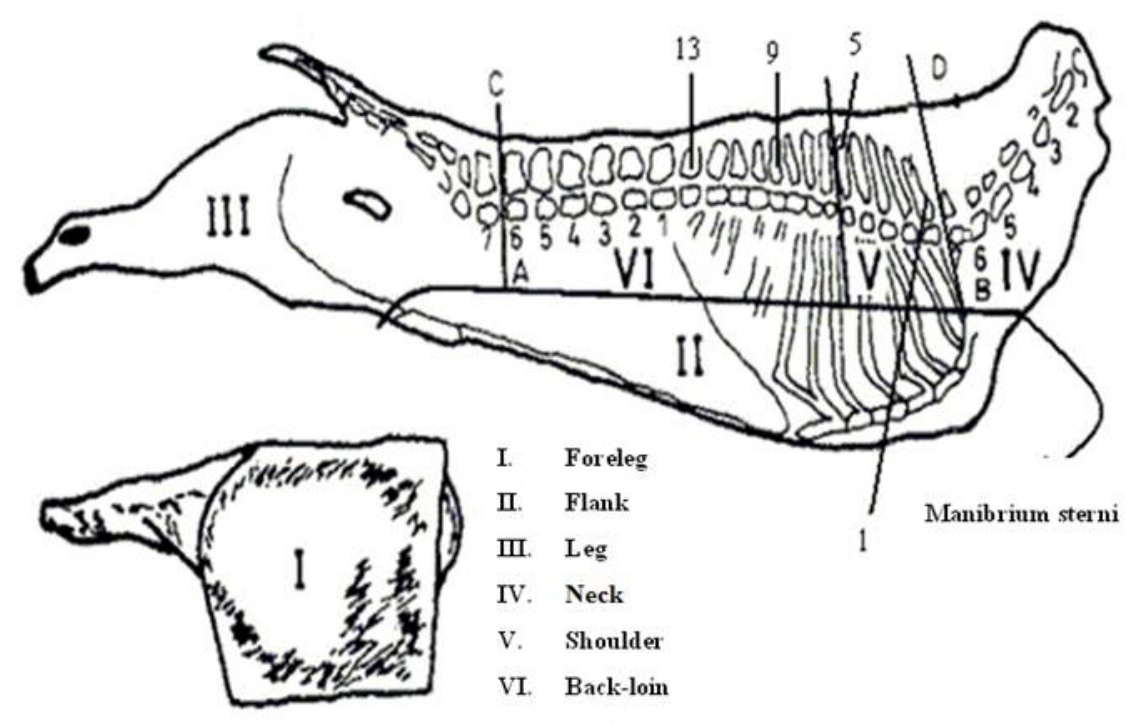

Figure 1 Cuts of carcass

Source: Colomer-Rocher et al. (1988)

The meat formation of the carcasses was classified as superior (S), excellent (E), very good (U), good $(\mathrm{R})$, fair $(\mathrm{O})$ and poor $(\mathrm{P})$. Also, fat scores of the carcasses were determined as 1 (low), 2 (slight), 3 (average), 4 (high) and 5 (very high). The meat formation and fat scores of the carcasses were determined subjectively using the colour template photographs of the S/EUROP classification system (Fisher \& De Boer, 1994; Ruiz de Huidobro et al., 2003). Each of the six classes for meat formation and five classes for fattiness were further divided into three sub-classes (low, medium and high). Thus, fat formation was graded on a scale of 1 to 15 and meat formation on a scale of 1 to 18 .

The data were analysed using the SPSS (1999) package programme. To analyse the data, the onesample Kolmogorov-Smirnov test was performed to examine normality. The test results showed that all data were distributed normally $(P>0.05)$. Levene's test for variance of homogeneity was performed to obtain information about homoscedasticity. The results showed that all data had similar variances $(P>0.05)$. Significant differences between means were tested with Duncan's test. The data involving meat formation and fat scores of the carcasses were analysed with Kruskal-Wallis $\mathrm{H}$ test. Mann-Whitney $\mathrm{U}$ test was used to compare binary groups.

\section{Results}

Weaning weight, slaughter weight and daily weight gain (DWG) during the fattening period of male lambs born to A, M, IW, KR, KV and MAM breeds are presented in Table 2. There were differences between lambs in weaning weight $(P<0.01)$. The IW lambs had a lower weaning weight than the other breeds $(P$ $<0.01)$. Although the mean slaughter weight was similar for all breeds, DWG of A lambs during the fattening period was higher $(P<0.01)$ than those of other breeds, except for MAM lambs.

Table 2 Weaning weight, slaughter weight and daily weight gain during fattening period of male lambs born to Akkaraman (A), Morkaraman (M), Awassi (IW), Karayaka (KR), Kıvırcık (KV) and Middle Anatolian Merino (MAM) Turkish indigenous sheep breeds

\begin{tabular}{lcccccc}
\hline Weights $(\mathbf{k g})$ & $\mathbf{A}(\mathbf{n}=\mathbf{6})$ & $\mathbf{M}(\mathbf{n}=\mathbf{6})$ & $\mathrm{IW}(\mathbf{n}=\mathbf{6})$ & $\mathrm{KR}(\mathbf{n}=6)$ & $\mathrm{KV}(\mathbf{n}=\mathbf{6})$ & MAM $(\mathbf{n}=\mathbf{6})$ \\
\hline Weaning & $30.4^{\mathrm{a}} \pm 1.0$ & $22.4^{\mathrm{c}} \pm 2.1$ & $13.7^{\mathrm{d}} \pm 1.1$ & $25.0^{\mathrm{abc}} \pm 1.1$ & $30.0^{\mathrm{ab}} \pm 1.5$ & $26.8^{\mathrm{abc}} \pm 0.9$ \\
Slaughter & $40.6 \pm 0.6$ & $40.1 \pm 0.3$ & $40.5 \pm 0.2$ & $40.4 \pm 0.3$ & $40.1 \pm 0.2$ & $40.0 \pm 0.4$ \\
DWG & $0.28^{\mathrm{a}} \pm 0.02$ & $0.23^{\mathrm{b}} \pm 0.02$ & $0.23^{\mathrm{b}} \pm 0.01$ & $0.15^{\mathrm{c}} \pm 0.02$ & $0.20^{\mathrm{bc}} \pm 0.01$ & $0.26^{\mathrm{ab}} \pm 0.04$
\end{tabular}


Slaughter characteristics of male lambs born to A, M, IW, KR, KV and MAM Turkish indigenous sheep breeds are presented in Table 3. Although the mean slaughter weight was similar for all breeds, cold carcass weight $(P<0.001)$ and cold dressing percentage $(P<0.001)$ in $\mathrm{A}, \mathrm{M}$ and IW lambs were lower than those of $\mathrm{KV}, \mathrm{KR}$ and MAM lambs. Lambs born to $\mathrm{M}$ had higher chilling loss percentage than those of other breeds $(P$ $<0.001)$. Fat depth over the $L D$ muscle was greater $(P<0.01)$ in $\mathrm{KV}$ and MAM lambs. The muscle area of $L D$ muscle was greater $(P<0.05)$ in MAM lambs than that of other breeds. Relative weights of pelt, head and visceral organs, except spleen, were significantly different between lambs born to $A, M, I W, K R, K V$ and MAM Turkish indigenous sheep breeds $(P<0.01)$. Table 4.

Carcass measurements of male lambs born to A, M, IW, KR, KV and MAM breeds are presented in

Table 3 Slaughter characteristics of male lambs born to Akkaraman (A), Morkaraman (M), Awassi (IW), Karayaka (KR), Kıvırcık (KV) and Middle Anatolian Merino (MAM) Turkish indigenous sheep breeds

\begin{tabular}{|c|c|c|c|c|c|c|}
\hline Items & $A(n=6)$ & $M(n=6)$ & IW $(n=6)$ & $K R(n=6)$ & $K V(n=6)$ & MAM $(n=6)$ \\
\hline Slaughter weight $(\mathrm{kg})$ & $40.6 \pm 0.58$ & $40.0 \pm 0.35$ & $40.5 \pm 0.18$ & $40.4 \pm 0.28$ & $40.1 \pm 0.23$ & $40.0 \pm 0.35$ \\
\hline Cold carcass weight $(\mathrm{kg})$ & $16.41^{\mathrm{b}} \pm 0.39$ & $16.40^{\mathrm{b}} \pm 0.16$ & $16.75^{\mathrm{b}} \pm 0.29$ & $18.15^{\mathrm{a}} \pm 0.52$ & $19.13^{\mathrm{a}} \pm 0.23$ & $19.14^{a} \pm 0.32$ \\
\hline Cold dressing percentage (\%) & $40.4^{\mathrm{C}} \pm 0.64$ & $40.9^{c} \pm 0.41$ & $41.3^{\mathrm{b}} \pm 0.74$ & $44.9^{\mathrm{ab}} \pm 1.09$ & $47.8^{\mathrm{a}} \pm 0.62$ & $47.9^{\mathrm{a}} \pm 0.66$ \\
\hline Chilling loss percentage (\%) & $2.09^{b c} \pm 0.08$ & $3.49^{\mathrm{a}} \pm 0.23$ & $2.60^{b} \pm 0.44$ & $2.68^{\mathrm{b}} \pm 0.15$ & $2.33^{b} \pm 0.27$ & $1.46^{c} \pm 0.34$ \\
\hline Fat depth of $L D(\mathrm{~mm})$ & $2.17^{\mathrm{b}} \pm 0.43$ & $1.99^{\mathrm{b}} \pm 0.43$ & $2.83^{\mathrm{ab}} \pm 0.43$ & $2.80^{\mathrm{ab}} \pm 0.39$ & $3.86^{a} \pm 0.39$ & $3.34^{a} \pm 0.39$ \\
\hline Muscle area of $L D\left(\mathrm{~cm}^{2}\right)$ & $14.59^{\mathrm{b}} \pm 1.29$ & $15.09^{b} \pm 1.29$ & $14.12^{\mathrm{b}} \pm 1.29$ & $14.19^{\mathrm{b}} \pm 1.18$ & $15.82^{\mathrm{b}} \pm 1.18$ & $18.98^{\mathrm{a}} \pm 1.18$ \\
\hline \multicolumn{7}{|c|}{ Non-carcass components (as $\%$ of slaughter weight) } \\
\hline Pelt & $9.10^{c} \pm 0.48$ & $10.14^{\mathrm{bc}} \pm 0.36$ & $11.71^{b} \pm 0.46$ & $15.43^{\mathrm{a}} \pm 1.09$ & $9.30^{c} \pm 0.26$ & $10.43^{\mathrm{bc}} \pm 0.49$ \\
\hline Head & $4.87^{\mathrm{bc}} \pm 0.07$ & $4.56^{c} \pm 0.03$ & $5.03^{b} \pm 0.13$ & $5.76^{a} \pm 0.20$ & $5.42^{\mathrm{ab}} \pm 0.23$ & $5.08^{b} \pm 0.09$ \\
\hline Feet & $2.63^{\mathrm{a}} \pm 0.05$ & $2.37^{b} \pm 0.07$ & $2.46^{b} \pm 0.10$ & $2.25^{\mathrm{b}} \pm 0.06$ & $2.41^{b} \pm 0.04$ & $2.32^{\mathrm{b}} \pm 0.04$ \\
\hline Heart & $0.48^{\mathrm{bc}} \pm 0.01$ & $0.50^{b c} \pm 0.02$ & $0.45^{c} \pm 0.01$ & $0.54^{\mathrm{ab}} \pm 0.01$ & $0.60^{\mathrm{a}} \pm 0.02$ & $0.58^{a} \pm 0.03$ \\
\hline Lungs & $1.43^{\mathrm{b}} \pm 0.05$ & $1.39^{\mathrm{b}} \pm 0.04$ & $1.36^{\mathrm{b}} \pm 0.01$ & $1.49^{b} \pm 0.04$ & $1.64^{\mathrm{a}} \pm 0.05$ & $1.35^{\mathrm{b}} \pm 0.04$ \\
\hline Spleen & $1.97 \pm 0.13$ & $1.45 \pm 0.28$ & $1.83 \pm 0.10$ & $1.64 \pm 0.06$ & $1.69 \pm 0.31$ & $1.97 \pm 0.12$ \\
\hline Liver & $1.89^{c} \pm 0.07$ & $2.21^{\mathrm{b}} \pm 0.09$ & $1.95^{\mathrm{ab}} \pm 0.03$ & $2.02^{\mathrm{ab}} \pm 0.07$ & $2.22^{\mathrm{a}} \pm 0.13$ & $1.85^{c} \pm 0.06$ \\
\hline
\end{tabular}

LD: longissimus dorsi muscle

${ }_{a, b, c}$ Differences indicated by different superscripts on the same row are significant at $P<0.05$

Table 4 Carcass measurements of male lambs born to Akkaraman (A), Morkaraman (M), Awassi (IW), Karayaka (KR), Kıvırcık (KV) and Middle Anatolian Merino (MAM) Turkish indigenous sheep breeds

\begin{tabular}{lcccccc}
\hline Items $(\mathbf{c m})$ & $\mathbf{A}(\mathbf{n}=\mathbf{6})$ & $\mathbf{M}(\mathbf{n}=\mathbf{6})$ & $\mathbf{I W}(\mathbf{n}=\mathbf{6})$ & $\mathbf{K R}(\mathbf{n}=\mathbf{6})$ & $\mathbf{K V}(\mathbf{n}=\mathbf{6})$ & $\mathbf{M A M}(\mathbf{n}=\mathbf{6})$ \\
\hline Carcass length & $61.0^{\mathrm{bc}} \pm 0.60$ & $60.6^{\mathrm{bc}} \pm 0.71$ & $59.7^{\mathrm{c}} \pm 0.99$ & $65.3^{\mathrm{a}} \pm 0.53$ & $64.1^{\mathrm{a}} \pm 0.36$ & $61.8^{\mathrm{b}} \pm 0.53$ \\
Pelvic limb length & $40.3^{\mathrm{a}} \pm 0.44$ & $37.8^{\mathrm{cd}} \pm 0.64$ & $39.3^{\mathrm{abc}} \pm 0.41$ & $39.9^{\mathrm{ab}} \pm 0.41$ & $36.8^{\mathrm{d}} \pm 0.94$ & $38.6^{\mathrm{bc}^{\mathrm{c}} \pm 0.59}$ \\
Hindquarter traits & & & & & & \\
Length & $36.3^{\mathrm{a}} \pm 0.47$ & $32.7^{\mathrm{b}} \pm 0.70$ & $33.7^{\mathrm{b}} \pm 1.19$ & $32.8^{\mathrm{b}} \pm 0.47$ & $31.9^{\mathrm{b}} \pm 0.99$ & $33.0^{\mathrm{b}} \pm 0.89$ \\
Width & $18.33 \pm 0.38$ & $19.26 \pm 0.42$ & $13.66 \pm 0.74$ & $13.65 \pm 0.38$ & $17.98 \pm 0.56$ & $19.26 \pm 0.42$ \\
Depth & $13.13 \pm 0.39$ & $13.70 \pm 0.58$ & $13.92 \pm 0.62$ & $13.02 \pm 0.60$ & $13.95 \pm 0.39$ & $13.70 \pm 0.58$ \\
Perimeter & $62.4^{\mathrm{ab}} \pm 0.28$ & $61.6^{\mathrm{bc}} \pm 0.67$ & $61.6^{\mathrm{bc}} \pm 0.91$ & $61.2^{\mathrm{bc}} \pm 0.57$ & $60.0^{\mathrm{c}} \pm 0.73$ & $63.7^{\mathrm{a}} \pm 0.43$ \\
Chest traits & & & & & & \\
Depth & $23.8^{\mathrm{a}} \pm 0.29$ & $23.4^{\mathrm{a}} \pm 0.12$ & $24.1^{\mathrm{a}} \pm 0.46$ & $23.5^{\mathrm{a}} \pm 0.32$ & $22.9^{\mathrm{ab}} \pm 0.39$ & $21.8^{\mathrm{b}} \pm 0.54$ \\
Width & $26.1 \pm 0.28$ & $26.1 \pm 0.32$ & $26.3 \pm 1.89$ & $26.1 \pm 0.81$ & $26.2 \pm 0.66$ & $26.2 \pm 0.22$ \\
\hline
\end{tabular}


The KR and KV lambs had higher $(P<0.001)$ carcass length than the other breeds. There were differences $(P<0.001)$ among breeds in pelvic limb length. Hindquarter length of the $A$ lambs was higher $(P$ $<0.01)$ than that of the other breeds. Moreover, hindquarter perimeters of lambs varied among breeds $(P$ $<0.05)$. There were no significant differences between chest width, hindquarter width and hindquarter depth among breeds. Relative weights (\%) of the left carcass cuts and composition of male lambs born to A, M, IW, $\mathrm{KR}, \mathrm{KV}$ and MAM breeds are presented in Table 5. The relative weight of shoulder was higher in the $\mathrm{A}$ and MAM lambs than that of the other breeds $(P<0.05)$. There were differences $(P<0.01)$ in relative weight of leg. Relative weight of back loin in KV and MAM lambs was greater than in the other breeds $(P<0.05)$. There were differences $(P<0.001)$ among breeds in relative weight of lean. Relative fat weights of $A$ and $M$ lambs were lower $(P<0.001)$ than those of the other breeds. Also, M lambs had heavy relative bone weight compared with other breeds $(P<0.001)$. Moreover, the ratio of lean to fat was lower $(P<0.001)$ in M lambs than in other breeds. However, the M lambs had higher lean-to-bone ratio compared with the other breeds $(P$ $<0.05)$.

Table 5 Relative weights (\%) of left carcass cuts and compositions of male lambs born to Akkaraman (A), Morkaraman (M), Awassi (IW), Karayaka (KR), Kıvırcık (KV) and Middle Anatolian Merino (MAM) Turkish indigenous sheep breeds

\begin{tabular}{lcccccc}
\hline Items $^{\ddagger}$ & $\mathbf{A}(\mathbf{n}=\mathbf{6})$ & $\mathbf{M}(\mathbf{n}=\mathbf{6})$ & $\mathbf{I W}(\mathbf{n}=\mathbf{6})$ & $\mathbf{K R}(\mathbf{n}=\mathbf{6})$ & $\mathbf{K V}(\mathbf{n}=\mathbf{6})$ & $\mathbf{M A M}(\mathbf{n}=\mathbf{6})$ \\
\hline \multicolumn{7}{l}{ Left carcass cuts } \\
Neck & $7.58 \pm 0.31$ & $7.00 \pm 0.44$ & $6.68 \pm 0.43$ & $7.28 \pm 0.35$ & $6.86 \pm 0.23$ & $6.69 \pm 0.23$ \\
Shoulder & $6.94^{\mathrm{a}} \pm 0.35$ & $4.86^{\mathrm{b}} \pm 0.31$ & $4.89^{\mathrm{b}} \pm 0.65$ & $5.35^{\mathrm{b}} \pm 0.28$ & $5.48^{\mathrm{b}} \pm 0.48$ & $6.93^{\mathrm{a}} \pm 0.73$ \\
Foreleg & $19.1 \pm 0.36$ & $19.0 \pm 0.16$ & $18.6 \pm 0.38$ & $17.2 \pm 0.41$ & $17.6 \pm 0.71$ & $18.8 \pm 0.68$ \\
Leg & $36.1^{\mathrm{a}} \pm 0.39$ & $35.8^{\mathrm{a}} \pm 0.67$ & $35.8^{\mathrm{a}} \pm 0.68$ & $33.4^{\mathrm{b}} \pm 0.69$ & $32.8^{\mathrm{b}} \pm 1.02$ & $33.2^{\mathrm{b}} \pm 0.78$ \\
Back loin & $17.5^{\mathrm{b}} \pm 0.72$ & $16.6^{\mathrm{b}} \pm 0.81$ & $16.1^{\mathrm{b}} \pm 0.80$ & $19.4^{\mathrm{a}} \pm 0.59$ & $17.6^{\mathrm{b}} \pm 1.23$ & $20.3^{\mathrm{a}} \pm 0.57$ \\
Flank & $11.77 \pm 0.76$ & $12.48 \pm 0.54$ & $13.84 \pm 0.43$ & $11.58 \pm 0.74$ & $13.48 \pm 0.62$ & $12.97 \pm 1.15$ \\
Left carcass compositions & & & & & \\
Lean & $57.7^{\mathrm{a}} \pm 0.98$ & $55.5^{\mathrm{ab}} \pm 1.23$ & $52.2^{\mathrm{b}} \pm 1.10$ & $48.3^{\mathrm{c}} \pm 0.69$ & $47.9^{\mathrm{c}} \pm 2.06$ & $53.4^{\mathrm{ab}} \pm 1.79$ \\
Fat & $19.9^{\mathrm{b}} \pm 1.20$ & $22.5^{\mathrm{b}} \pm 1.83$ & $27.2^{\mathrm{a}} \pm 1.41$ & $29.8^{\mathrm{a}} \pm 0.75$ & $31.5^{\mathrm{a}} \pm 1.80$ & $28.2^{\mathrm{a}} \pm 1.99$ \\
Bone & $19.1^{\mathrm{a}} \pm 0.86$ & $15.7^{\mathrm{b}} \pm 0.82$ & $14.4^{\mathrm{bc}} \pm 0.74$ & $13.4^{\mathrm{bc}} \pm 0.81$ & $12.1^{\mathrm{c}} \pm 0.28$ & $14.7^{\mathrm{b}} \pm 0.91$ \\
Lean/fat & $3.05^{\mathrm{b}} \pm 0.11$ & $3.57^{\mathrm{a}} \pm 0.15$ & $3.64^{\mathrm{a}} \pm 0.13$ & $3.64^{\mathrm{a}} \pm 0.21$ & $3.97^{\mathrm{a}} \pm 0.16$ & $3.70^{\mathrm{a}} \pm 0.21$ \\
Lean/bone & $2.97^{\mathrm{a}} \pm 0.23$ & $2.49^{\mathrm{b}} \pm 0.14$ & $1.96^{\mathrm{c}} \pm 0.14$ & $1.64^{\mathrm{c}} \pm 0.06$ & $1.54^{\mathrm{c}} \pm 0.13$ & $1.97^{\mathrm{c}} \pm 0.19$
\end{tabular}

${ }^{a, b, c}$ Differences indicated by different letters on the same line are significant at $P<0.05$

${ }^{\neq}$As $\%$ of the left part weight of carcass

Carcass classes and indices of male lambs born to $A, M, I W, K R, K V$ and MAM breeds are presented in Table 6. The highest value for carcass fleshiness was obtained in MAM and IW lambs $(P<0.01)$. In contrast, the lowest value for carcass fatness score was obtained in MAM and IW lambs $(P<0.01)$. There were differences among breeds in carcass compactness $(P<0.01)$ and leg conformation $(P<0.05)$, while the differences in carcass conformation among breeds were not significant.

\section{Discussion}

The most important factors that affect carcass weight and quality are genotype (Yilmaz et al. 2009), slaughter age and weight (Abdullah \& Sudsier, 2008; Yakan \& Unal, 2010), sex (Sen et al., 2011), birth type (Ekiz et al., 2012b), nutrition (Alhidary et al., 2016a; Alhidary et al., 2016b; Abdelrahman et al., 2017) and raising system (Ekiz et al., 2012a). It was reported that carcass weight and dressing percentage increased with greater slaughter weight of lambs (Yakan \& Unal, 2010; Aksoy \& Ulutas, 2015). In this study, all lambs born to A, M, IW, KR, KV and MAM breeds were slaughtered at a mean live weight of $40 \mathrm{~kg}$ and significant differences were observed among breeds in cold carcass weight and cold dressing percentage. In the present study A, M and IW lambs, which are fat-tailed breeds, had lower cold carcass weight and cold dressing percentage compared with $\mathrm{KV}, \mathrm{KR}$ and $\mathrm{AM}$ lambs, which are thin-tailed breeds. The dressing 
Table 6 Carcass classes and indices of male lambs born to Akkaraman (A), Morkaraman (M), Awassi (IW), Karayaka (KR), Kıvırcık (KV) and Middle Anatolian Merino (MAM) Turkish indigenous sheep breeds

\begin{tabular}{|c|c|c|c|c|c|c|}
\hline Items (cm) & $A(n=6)$ & $M(n=6)$ & IW $(n=6)$ & $\mathrm{KR}(n=6)$ & $K V(n=6)$ & $\operatorname{MAM}(n=6)$ \\
\hline \multicolumn{7}{|l|}{ Carcass classes } \\
\hline Fleshiness & $\begin{array}{c}5.17^{\mathrm{C}} \pm 0.44 \\
(\mathrm{O})\end{array}$ & $\begin{array}{c}5.20^{\mathrm{C}} \pm 0.48 \\
(\mathrm{O})\end{array}$ & $\begin{array}{c}7.80^{\mathrm{ab}} \pm 0.48 \\
(\mathrm{R})\end{array}$ & $\begin{array}{c}6.40^{\mathrm{bc}} \pm 0.48 \\
(+O)\end{array}$ & $\begin{array}{c}7.40^{\mathrm{ab}} \pm 0.48 \\
(-\mathrm{R})\end{array}$ & $\begin{array}{c}8.00^{a} \pm 0.44 \\
(R)\end{array}$ \\
\hline Fatness & $\begin{array}{c}8.83^{\mathrm{ab}} \pm 0.46 \\
(+3)\end{array}$ & $\begin{array}{c}9.00^{\mathrm{ab}} \pm 0.51 \\
(+3)\end{array}$ & $\begin{array}{c}7.60^{1} \pm 0.51 \\
(3)\end{array}$ & $8.20^{\mathrm{b}} \pm 0.51$ & $\begin{array}{c}10.00^{\mathrm{a}} \pm 0.51 \\
(-4)\end{array}$ & $\begin{array}{c}7.50^{10} \pm 0.46 \\
(3)\end{array}$ \\
\hline Compactness & $0.30^{\mathrm{a}} \pm 0.01$ & $0.26^{\mathrm{e}} \pm 0.01$ & $0.28^{c} \pm 0.01$ & $0.29^{b} \pm 0.01$ & $0.28^{c} \pm 0.01$ & $0.27^{d} \pm 0.01$ \\
\hline \multicolumn{7}{|l|}{ Carcass indices } \\
\hline $\begin{array}{l}\text { Carcass } \\
\text { conformation }\end{array}$ & $0.42 \pm 0.01$ & $0.42 \pm 0.01$ & $0.44 \pm 0.01$ & $0.40 \pm 0.01$ & $0.44 \pm 0.01$ & $0.43 \pm 0.01$ \\
\hline Leg conformation & $0.57^{\mathrm{a}} \pm 0.01$ & $0.50^{b} \pm 0.01$ & $0.56^{\mathrm{ab}} \pm 0.01$ & $0.57^{\mathrm{a}} \pm 0.01$ & $0.55^{\mathrm{ab}} \pm 0.01$ & $0.60^{a} \pm 0.02$ \\
\hline
\end{tabular}

$a, b, c$ The differences indicated by different superscripts on the same row are significant at $P<0.05$

O: fair, +O: high-fair, -R: low-good, R: good, 3: average, +3: high-average, -4: low-high)

percentage of KV and KR lambs was similar to observations by Gokdal et al. (2012) and Sen et al. (2011), who reported that dressing percentages of $\mathrm{KV}$ and $\mathrm{KR}$ lambs that were subjected to intensive fattening programmes were 48.1 and $45.0 \%$, respectively. However, the dressing percentages of the M, IW, MAM and A lambs were lower than the findings of Macit (2002), which were $49.5 \%$ for M, Tekel et al. (2007), 50.1\% for IW, Ekiz et al. (2009), 57.1\% for MAM and Akcapinar (1981) 49.1\% for A. The results of this study showed that the highest cold dressing percentage was determined in MAM lambs, and the lowest in A lambs. Also, the highest fat depth value was observed in MAM lambs and the lowest in A lambs. The highest fat depth value could be the result of a higher cold dressing percentage in MAM lambs. The current study indicated that, except for the A lambs, chilling loss percentage decreased with increasing back fat depth. Similar to the current results, Yılmaz et al. (2009) reported higher chilling loss in Imroz lambs, which have lower back fat thickness than Turkish Merino, Ramlıç, and Kıvırcık lambs. The KR lambs have longer-haired fleece among the indigenous breeds (YIImaz et al., 2012). Therefore, the relative weight of the pelt was higher in KR lambs compared with the other Turkish native breeds in the present study. Also, $\mathrm{A}$ and $\mathrm{M}$ lambs had lower relative weight of the head than the other Turkish native breeds. The $A$ and $M$ breeds do not normally have horns (Yılmaz et al., 2012), which may explain the low head weight percentages in these breeds. Additionally, differences were observed between breeds in heart, lungs and liver, which are defined as supply organs.

In the present study, the lamb carcass measurements were higher than those reported by Russo et al. (2003). This difference may be because the A, M, IW, KV, KR, and MAM lambs had heavy carcass weights. Also, the carcass length and carcass weight values of the $A, M$ and IW lambs were lower than those of the KV, KR and MAM lambs. Santos et al. (2007) reported that an increase in the carcass weight of lambs was related to an increase in carcass measurements. The external hindquarter and pelvic limb length of $A$ lambs and the hindquarter perimeter of MAM lambs were higher than those of the other breeds. These differences may be explained by breed traits of $A$ and MAM lambs because carcass measurements can vary between breeds (Santos et al., 2007).

The lean percentages in carcasses of the $A, M$ and MAM lambs were higher than those of other Turkish native breeds. The $A$ and $M$ lambs had low fat percentages compared with the other breeds. These results could be because $A$ and $M$ are fat-tailed breeds. Subjectively, the highest fat percentages were observed in KR lambs, because Karayaka is a small-sized local breed. Sañudo et al. (1998) reported that small breeds had lower bodyweights and more fat than large breeds when lambs were slaughtered at same age. The mature weight of KR sheep breed was lower (approximately 35-40 kg) compared with A (approximately 45-50 kg), M (approximately 50-60 kg), IW (approximately 45-50 kg), KV (approximately 45-50 kg), and MAM (approximately 50-55 kg) (Yılmaz et al., 2012).

Generally, consumers prefer the leg and back loin parts of lamb carcasses. This should be taken into account to meet consumer preferences. Also, parts of carcasses may vary in the quality and quantity of the meat (Aksoy \& Ulutas, 2015). In the present study, the A and MAM lambs had higher shoulder percentages than those of the other breeds. Leg percentages of the $A, M$, and IW lambs were higher than those of the $\mathrm{KV}, \mathrm{KR}$ and MAM lambs. Greater back loin percentages were observed in the KV and MAM compared with the other breeds. In the present study, the percentages of portions of carcasses such as the neck, shoulder, foreleg, leg, back loin and flank percentage were mostly similar to previous studies at approximately the 
same age, namely A and M (Teke \& Ünal, 2009), IW (Abdullah \& Qudsieh, 2008), KV (Karabacak, 2007), KR (Aksoy \& Ulutas, 2015) and MAM (Tekin et al., 2005; Teke \& Ünal, 2009).

Carcass classification is one of the most important indicators of carcass quality and fatness condition (Russo et al., 2003). In the present study, the fleshiness score of KV lambs (7.40) was lower than the results of Yilmaz et al. (2009), who reported that at $47 \mathrm{~kg}$ live weight, the fleshiness score of $\mathrm{KV}$ lambs that were reared under intensive conditions was 8.60. However, the current findings are similar to the results of Ekiz et al. (2012b), in which KV lambs were slaughtered at 120 days old. In the present study the fatness scores of all lambs born to Turkish native breeds were higher than the results of Ekiz et al. (2012a), in which KV lambs were raised in four production systems. Onenc et al. (2009) reported that the carcass classifications of $\mathrm{A}, \mathrm{M}, \mathrm{IW}$ and $\mathrm{KV}$ yearling lambs were determined as $\mathrm{R}-/ \mathrm{R}, \mathrm{O}+/ \mathrm{R}-, \mathrm{O}$, and $\mathrm{O}+$, and that the fatness degree of these lambs was 4, $4-, 3-/ 3+$, and $3 / 3+$, respectively. In this study, the carcass classification and fatness degree of the $\mathrm{A}, \mathrm{M}, \mathrm{IW}, \mathrm{KV}, \mathrm{KR}$, and MAM lambs were recorded as $\mathrm{O}, \mathrm{O}, \mathrm{R}, \mathrm{R}-, \mathrm{O}+$ and $\mathrm{R}$, and $+3,+3,3,-4,3$ and 3 , respectively. The carcass classification and fatness degree of $A$ lambs were lower, but the same trait for IW and KV lambs was higher than the values reported by Onenc et al. (2009). However, the results were similar to the values reported by Onenc et al. (2009) for M lambs. These differences may be explained by feeding, slaughter age and weight and raising or management differences of lambs between studies.

\section{Conclusion}

The purpose of the present study was to determine comparatively the slaughter and carcass traits of A, M, IW, KR, KV, and MAM male lambs under intensive production systems. It was found that, subjectively, the $A$ lambs had higher lean percentages than the M, IW, KR, KV and MAM lambs. However, the lean percentages of M, IW and MAM lambs were nearly the same as the A lambs. In this study, KV, KR and MAM lambs had higher dressing percentages than the A, M and IW lambs. Lambs born to the $A$ breed had relatively higher neck, shoulder, foreleg and leg percentages than those of lambs born to other Turkish native breeds. The KV and MAM lambs had greater back loin percentages than those of lambs born to other Turkish native breeds. The current study revealed that conformation and fatness scores were generally $0 / 3$ when the lambs of indigenous Turkish native breeds reached a mean live weight of $40 \mathrm{~kg}$ under intensive production systems.

In this study, it was determined that the A and MAM lambs had relatively higher DWG. The lean percentage of $A, M$ and IW lambs was higher than those of $K V, K R$ and MAM lambs when the lambs reached a mean live weight of $40 \mathrm{~kg}$ under intensive production systems. Nevertheless, the cold dressing percentages of the A, M and IW lambs were lower than those of the KV, KR and MAM lambs. MAM lambs had a lower carcass fatness score, but higher carcass fleshiness. Also, carcass compactness and leg conformation traits showed differences among breeds. Therefore, A and MAM lambs could be recommended for intensive production systems as lambs of indigenous breeds.

\section{Acknowledgments}

Authors wish to thank General Directorate of Agricultural Researches and Policies of Turkey (Project no: TAGEM 10/AR-GE/13) for their financial support for the present research

\section{Authors' Contributions}

YA, MU and EŞ collected the data, ÜÇ and AÖ drafted the manuscript. ZU, MK, UŞ designed the study, analysed the data and revised the manuscript.

\section{Conflict of Interest Declaration}

We certify that there is no conflict of interest with any financial organization regarding the material discussed in the manuscript.

\section{References}

Abdelrahman, M.M., Alhidary, I., Alyemni, A.H., Khan, R.U., Bello, A.R.S., Al-Saiady, M.Y. \& Amran, R.A., 2017. Effect of alfalfa hay on rumen fermentation patterns and serum biochemical profile of growing Naemi lambs with ad libitum access to total mixed rations. Pakistan J. Zool. 49, 1519-1522.

Abdullah, A.Y. \& Qudsieh, R.I., 2008. Carcass characteristics of Awassi ram lambs slaughtered at different weights. Livest. Sci. 117, 165-175.

Akcapinar, H., 1981. Researches on the meat production and carcass characteristics of Daglic, Akkaraman and Kivircik lambs slaughtered at different slaughter weights. Firat Univ. Vet. J. Health Sci. 6, 165-184

Aksoy, Y. \& Ulutas, Z., 2015. Effect of different slaughter weights on slaughter and carcass traits of male Karayaka lambs reared under intensive production system. Turk. J. Agri. Food Sci. Technol. 3, 406-412.

Alhidary, I.A., Abdelrahman, M.M. \& Khan, R.U., 2016a. Comparative effects of direct-fed microbial alone or with a traces mineral supplement on the productive performance, blood metabolites and antioxidant status of grazing Awassi lambs. Environ. Sci. Pollut. Res. 23, 25218-25223. 
Alhidary, I.A., Abdelrahman, M.M., Alyemni, A.H., Khan, R.U., Al-Saiady, M.Y., Amran, R.A. \& Alshamiry, F.A., 2016b. Effect of alfalfa hay on growth performance, carcass characteristics, and meat quality of growing lambs with ad libitum access to total mixed rations. R. Bras. Zootec. 45, 302-308.

Colomer-Rocher, F., Delfa, F. \& Sierra, I., 1988. Métodos normalizados para el estudio de los caracteres cuantitativos y cualitativos de las canales caprinas y ovinas. Madrid; INIA, 1988. $41 \mathrm{p}$.

Ekiz, B., Yilmaz, A., Ozcan, M., Kaptan, C., Hanoglu, H., Erdogan, I. \& Yalcintan, H., 2009. Carcass measurements and meat quality of Turkish Merino, Ramlıç, Kıvırcık, Chios and İmroz lambs raised under an intensive production system. Meat Sci. 82, 64-70.

Ekiz, B., Yılmaz, A., Özcan, M. \& Kocak, O., 2012a, Effect of production system on carcass measurements and meat quality of Kivircik lambs. Meat Sci. 90, 465-471.

Ekiz, B., Ekiz, E.E., Yalcintan, H., Kocak, O. \& Yılmaz, A., 2012b. Effects of suckling length (45, 75 and 120 d) and rearing type on cortisol level, carcass and meat quality characteristics in Kivircik lambs. Meat Sci. 92, 53-61.

Fisher, A.V. \& De Boer, H., 1994. The EAAP standard method of sheep carcass assessment. Carcass measurements and dissection procedures report of the EAAP working group on carcass evaluation in cooperation with the CIHEAM Instituto Agronomico Mediterraneo of Zaragoza and the CEC Directorate General for Agriculture in Brussels. Livest. Prod. Sci. 38, 149-161.

Gokdal, O., Atay, O., Eran, V. \& Demircioglu, S.K., 2012. Fattening performance, carcass and meat quality characteristics of Kivircik male lambs. Trop. Anim. Health Prod. 44, 1491-1496.

Karabacak, A., 2007. Fattening performance and carcass characteristics of some fat tailed and thin tailed sheep breeds. PhD thesis, Selcuk University, Konya, Turkey,

Macit, M., 2002. Growth and carcass characteristics of male lambs of the Morkaraman breed. Small Rumin. Res. 43, 191-194.

Onenc, A., Taskin, T., Kayaardi, S., Ozdogan, M., Metin, K., Ateslier, Z.B.B., Arat, O. \& Aksit, H., 2009. A study on the evaluation of carcass and meat quality of common, slaughtered cattle and sheep breeds in Turkey under EUROP classification system. TUBITAK, Project No: 1060722.

Ruiz de Huidobro, R., Miguel, E., Diazi, M.T., Velasco, S., Lauzurica, S., Perez, C., Onega, E., Blazquez, B. \& Caneque, V., 2003. Carcass classification in suckling lambs. II. Comparison among subjective carcass classification methods: fatness scales and conformation scales with 0.25 point-intervals. Meat Sci. 66, 135-142.

Russo, C., Preziuso, G. \& Verità, P., 2003. EU carcass classification systems: Carcass and meat quality in light lambs. Meat Sci. 64, 411-416.

Santos, V.A., Silva, S.R., Mena, E.G. \& Azevedo, J.M.T., 2007. Live weight and sex effects on carcass and meat quality of Borrego Terrincho-PDO suckling lambs. Meat Sci. 77, 654-661.

Sañudo, C., Sanchez, A. \& Alfonso, M., 1998. Small ruminant production systems and factors affecting lamb meat quality. Meat Sci. 49, 29-64.

Sen, U., Sirin, E., Ulutas, Z. \& Kuran, M., 2011. Fattening performance, slaughter, carcass and meat quality traits of Karayaka lambs. Trop. Anim. Health Prod. 43, 409-416.

SPSS, 1999. Statistical Package for the Social Sciences, 10.0. SPSS Inc., Chicago, IL, USA.

Teke, B. \& Ünal, N., 2009. The effects of slaughter weight and sex on some slaughter traits of Akkaraman and Morkaraman and Turkish Merino lambs. Vet. J. Ankara Univ. 56, 289-296.

Tekel, N., Sireli, H.D. \& Vural, M.E., 2007. The effect of fattening period on the fattening ability and carcass of male Awassi lambs. J. Agri. Sci. 13, 372-378.

Tekin, M.E., Gurkan, M., Karabulut, A. \& Düzgün, H., 2005. Performance testing studies and the selection of Hasmer, Hasak, Hasiv and Linmer crossbreed sheep types: II. Pre-weaning growth. Turk. J. Vet. Anim. Sci. 29, 59-65.

Tufarelli, V., Khan, R.U. \& Laudadio. V., 2011. Feeding of wheat middlings in lamb total mixed rations: effects on growth performance and carcass traits. Anim. Feed Sci. Technol. 17(1), 130-135.

Tufarelli, V., Khan, R.U., Mazzei, D. \& Laudadio, V., 2012. Performance and carcass measurements of ewe lambs reared in a feedlot and fed wheat (Triticum durum Desf.) middling total mixed rations in the summer season. Trop. Anim. Health Prod. 44, 779-784.

TurkStat (Turkish Statistical Institute), 2018. Livestock Statistics. http://www.turkstat.gov.tr (accessed January 19, 2018).

Vacca, G.M., Carcangiu, V., Dettori, M.L., Pazzola, M., Mura, M.C., Luridiana, S. \& Tilloca, G., 2008. Productive performance and meat quality of Mouflon $\times$ Sarda and Sarda $\times$ Sarda suckling lambs. Meat Sci. 80, 326-334.

Yakan, A. \& Unal, N., 2010. Meat production traits of a new sheep breed called Bafra in Turkey I. fattening, slaughter, and carcass characteristics of lambs. Trop. Anim. Health Prod. 42, 751-759.

Yilmaz, A., Ekiz, B., Ozcan, M., Kaptan, C., Hanoglu, H., Erdogan, I. \& Kocak, O., 2009. Carcass traits of improved and indigenous lamb breeds of north-western Turkey under an intensive production system. Ital. J. Anim. Sci. 8, 663-675.

Yılmaz, O., Wilson, R.T., Kor, A., Cengiz, F. \& Ertuğrul, M., 2012. The farm animal genetic resources of Turkey: sheep I. Common and rare breeds. Bitlis Eren Univ. J. Sci. Technol. 2, 1-5. 